\title{
Housing Choices of Older People: Staying or Moving in the Case of High Care Needs
}

\author{
Maša Filipovič Hrast ${ }^{1} * * \mathbb{B}$, Richard Sendi ${ }^{2}$ and Boštjan Kerbler ${ }^{2}$ (i) \\ 1 Faculty of Social Sciences, University of Ljubljana, Kardeljeva ploščad 5, SI-1000 Ljubljana, Slovenia \\ 2 Urban Planning Institute of the Republic of Slovenia, Trnovski pristan 2, SI-1000 Ljubljana, Slovenia; \\ richard.sendi@uirs.si (R.S.); bostjan.kerbler@uirs.si (B.K.) \\ * Correspondence: masa.filipovic@fdv.uni-lj.si
}

Received: 10 January 2020; Accepted: 28 March 2020; Published: 4 April 2020

\begin{abstract}
Despite the development of various housing options across Europe, older people often face the choice of staying at home with the support of family and/or formal services or moving to a care home, but how people vary regarding these preferences and how newer cohorts will be different is under-researched. This study explores the housing choices of older people under the condition of liminality, which is defined as the hypothetical condition of high care needs. The most common choices available are compared; that is, staying at home (with social home-care support or visits to a daycare centre) or moving to supported housing or a care home. Cluster analysis revealed five distinct groups of older people that were differentiated in their choices between various options of moving versus staying at home, either by using home care or daycare. Differences between the clusters along three dimensions that influence decisions to move or stay, namely levels of attachment, satisfaction with housing and availability of support, which often function as limits on the options that are preferred, were explored. The results present the complexity of the decision-making process under imagined conditions of liminality and show a great diversity among people's preferences. They also indicate that a significant share of older people have a strong preference for only one option (two of the cluster groups).
\end{abstract}

Keywords: older people; housing choices; liminality; place attachment; satisfaction; social support

\section{Introduction}

In ageing Western societies, the issues of quality of ageing and care in old age are at the forefront of research and policy agendas. All projections indicate a significant increase of older people as a share of the total population, by approximately $10 \%$ from the present to 2080 [1]. Despite the development of various housing options across Europe, such as continuing care retirement communities, various forms of alternative housing, shared housing and supported housing [2,3], older people often face the choice of staying at home with the support of family or formal services, or moving to supported housing or a care home. As research has suggested, moving is most often triggered by poorer health and therefore higher care needs, which are important push factors [4-8]. Moving into a care home is often perceived as the last option and undesirable [3,9], or as a change that must be resisted because of an associated loss of autonomy [10,11], even though some studies show a high(er) quality of life in such environments [12].

Older people's reasoning and decision-making about where they want to grow old is an important issue that still needs to be further investigated [13] to understand and develop housing according to the diversifying preferences of older people, especially taking into account the newer cohorts that will become the target group for these housing developments in the future. Therefore, this study addresses this gap in the literature and adds to the understanding of the preferences of older people for care and 
housing in the case of care needs. It is based on an imagined condition of "liminality", in which the certainty of being at home is challenged by the possibility of having to move, mainly due to the loss of autonomy [10]. The concept of liminality was introduced in 1909 by Arnold van Gennep, who defined it as a state of "in between-ness" [14]. At a moment of liminality, people are defined as belonging to neither one category nor another [15]. The condition of being in between can refer to a relatively brief condition within the window of decision-making, but it can also relate to a longer period of evaluation and re-evaluation of the position of an individual, satisfaction with the current living arrangement and the consideration of moving. Therefore, according to Grenier [16], liminality holds great potential regarding understanding transitions in later life; namely for understanding what is known or expected about older peoples' choices and needs. Leibing et al. [10] presented this as a potential specific moment in life (i.e., a moment of liminality), where choices regarding living conditions need to be made due to declining health, or a more static state of constant uncertainty regarding a specific present or future life circumstances.

Another specific motivation for this study is the need to investigate housing preferences in a region that is understudied and especially has its specifics due to the limited choices available to older people. The principle aim is to bridge the knowledge gap that currently exists in the approaches to developing appropriate housing and care facilities to address the needs and preferences of older people, while also taking into account the heterogeneity of this group. This study took place within central and eastern Europe, a region with high rates of home ownership [17] but relatively poor development of long-term care services to support ageing in place with a high quality of life [18,19]. In Slovenia, these characteristics are combined with a low availability of alternative housing options [20] and a traditionally well-developed institutional sector (i.e., care homes [21]); however, care homes are often perceived as the least preferred option [9] and also an increasingly expensive one [22]. These conditions frame an important context of a high reluctance to move from an individual home even though the support for remaining there is low, and this can have important implications for the quality of ageing in place. These specific conditions require a more in-depth investigation of decisions regarding moving versus staying, especially under conditions of higher care needs.

This study addressed the issue of housing choices in old age and contributes to the understanding of the complex topic of moving into a care facility or staying at home in old age, which is when health and care needs increase. The primary aim of this study was to explore the determinants of housing choice under the (hypothetical) condition of high care needs. The most common choices available are compared; that is, (a) staying at home (with social home-care support or visits to a daycare centre) or (b) moving to supported housing or a care home. The results of this analysis contribute to the understanding of this choice by analysing whether people most often decide between these two options, whether they perhaps find one option much more preferable to the other or whether they see one as not possible at all such that there is no actual decision between them. The diversity of choices people consider is often not presented and analysed in the literature, and they are limited to binary positions of ageing in place versus moving, not recognising the variety of choices within staying or different directions of moving. The study also addresses the question of whether the choices that are acceptable to older people limit this binary decision-making process to what is effectively no meaningful choice, or whether a wider recognition of options is available.

\section{Related Literature}

The majority of research today indicates that people wish to age in place [23-25] because this fosters independence, higher levels of control and a higher quality of life. Research shows that the majority of seniors prefer not to move, with this tendency growing stronger with age [3,26-28]. This is therefore also an important policy goal. The European Union (EU) and international organisations, such as the United Nations and the World Health Organization, have adopted the term "ageing in place", which formed the basis for the development of cross-national policy guidelines. On this basis, an action plan was agreed upon at the Second World Assembly on Ageing in 2002. The document 
represented a starting point for implementing policies regarding the demands of older people in terms of health care and housing within the EU, and it supports older people living in their homes, despite having a disability or illness [29].

However, ageing in place is a process of continual adaptation to external and internal changes. It is not a uniform experience or solution, and preference for it or even its feasibility will depend upon evolving life-course needs [30]. A considerable number of studies have investigated the living conditions that trigger changes in the lives of older people [31-33]. Under conditions of high care needs, for example, the transition to a more supportive environment may become necessary or current residences may need to be adapted (e.g., Perry et al. [34]). Because moving is most often triggered during conditions of poor health and high care needs (e.g., References [4-8]), this was used as a starting point of this analysis, presuming a hypothetical situation of high-care needs. Here, a very useful concept is that of liminality, or the in-between position where choices are considered (see Leibing et al. [10]). Inducing this imagined state of liminality in respondents, i.e., having high care needs that limit their ability to remain in their current housing independently and asking them about the preferences under these conditions, sheds light on the choices and decisions people make under conditions that are a relevant trigger for moving house.

A literature review identified three important dimensions influencing decisions to stay or move, which were further analysed in this study. These are the availability of support, attachment to home and housing satisfaction.

Woodbridge [35] emphasised the meaning of home as an important motive that affects older adults' decisions to stay or move from their current residences (see also Giuliani [36]), as well as the psychological attachment to home [37]. Attachment to a place (i.e., to one's home and also the wider neighbourhood) therefore affects older adults' mobility and is the reason people choose to stay at home even if they are unable to maintain their quality of life [13,38,39]. Understanding various aspects of this attachment can be effective in assessing older people's reasoning about staying or moving from their homes. Hidalgo and Hernandez [24] defined attachment to place as a bond between people and specific places. It is a socially constructed phenomenon that consists of affective, cognitive and behavioural elements [24,40]. For Phillips et al. [39], place attachment is closely associated with ageing in place and includes wellbeing, independence and autonomy. Attachment to a place is linked to memories and identity-building [26,41-44]. Lawton [45] viewed place attachment as a transaction between an ageing individual and his or her residential environment that is characterised by changes in both the person and environment over time. The attachment and social bonds are therefore linked to specific material things within the home or through emotional bonds with the wider neighbourhood, emphasising its utility as well as social bonds [10,46]; furthermore, they are part of one's self-identity, making possible for the maintenance of valued roles [11].

The second dimension that strongly influences decisions to stay versus move is residential satisfaction. Older people need well-built, safe, secure and comfortable homes and neighbourhoods, as well as easy access to services, a supportive social network, healthcare and recreation; furthermore, they have a diverse range of aspirations and needs related to housing (see Bevan [47]). Wiseman [33] stressed that all people are continuously re-evaluating their domestic situation according to their needs, desires, resources and perceptions of potential outcomes, and decisions to move in old age are linked to the fit between the person and the environment [48]. Of importance are both satisfaction with the home and the wider environment, such as the building or neighbourhood (quality environment, transport, function and walkability) [49-51]. Hillcoat-Nallétamby and Ogg [30] stressed that a significant proportion of older people do wish to move because they dislike their current home environments. Relative satisfaction with one's current home and location also indicates the utility of the home for the older person and how well it allows for a suitable quality of life and responds to the needs of the ageing individual (e.g., References [52,53]).

Another important determinant of housing choice observed in this article is the availability of social support networks, which are an important element that enable older people to stay at home 
and to age in place. Childless and single people are more likely to move and more commonly live in institutionalised settings [54]. This confirms a study by Longino and Bradley [55], who indicated that reasons to move in later life differ between people living alone and cohabiting people. Because one of the primary carers is usually a partner, the death of a partner can also present an important triggering event for considering relocation [8]. Relocation and housing decisions are therefore linked to the availability of social support networks and to the location of the closest kin, such as children, as well as the quality of parent-child relationships (see Perry et al. [34]). The lack of a social support network can induce people to move even under conditions where they would otherwise be able to stay and age in place with appropriate support.

\section{Materials and Methods}

The research presented here was based on a survey of 930 people aged 50 and older, conducted in November 2015 using a computer-assisted telephone interview (CATI) surveying technique. The inclusion of a lower age cohort than the 65+ that is generally used was because younger people's housing preferences will be different from those of the current older population [54-56] and this selection aimed to capture this potential change. The sampling frame was the Slovenian telephone directory (TIS) and respondents were selected using the "last birthday" method. The final sample frame was 4100 , after the elimination of $30 \%$ of the initial, general population. The response rate was $22.6 \%$, resulting in 930 completed questionnaires. The data were cleaned for outlying values before being analysed and were weighted by region and sex. Descriptive statistics of the sample are presented in Table 1a,b. The characteristics of the resulting sample were checked before the analysis and the final sample included in the cluster analysis.

Table 1. (a): Descriptive statistics of the sample (\%); (b): Descriptive statistics of the sample (mean).

\begin{tabular}{|c|c|}
\hline \multicolumn{2}{|l|}{$\mathbf{a}$} \\
\hline Variables & Value \\
\hline \multicolumn{2}{|l|}{ Sex } \\
\hline Female & 56 \\
\hline Male & 44 \\
\hline \multicolumn{2}{|l|}{ Education } \\
\hline Primary school & 18.3 \\
\hline Specialised secondary school & 19.2 \\
\hline High school & 39.3 \\
\hline Tertiary school or university & 23.2 \\
\hline \multicolumn{2}{|l|}{ Income } \\
\hline Can live on current income without difficulty & 40.3 \\
\hline Can just about cope on current income & 46.7 \\
\hline Can barely get by on current income & 8.2 \\
\hline Can get by on current income with extreme difficulty & 4.7 \\
\hline \multicolumn{2}{|l|}{ Health condition } \\
\hline Very poor & 2.3 \\
\hline Poor & 9.0 \\
\hline Satisfactory & 42.8 \\
\hline Good & 34.4 \\
\hline Very good & 11.5 \\
\hline
\end{tabular}


Table 1. Cont.

\begin{tabular}{|c|c|}
\hline \multicolumn{2}{|l|}{ Hindering chronic illness } \\
\hline Yes, very & 12.1 \\
\hline Yes, to some degree & 30.5 \\
\hline No & 57.4 \\
\hline \multicolumn{2}{|l|}{ Location of residence } \\
\hline In the countryside & 45.3 \\
\hline In a small settlement or a small town & 30.4 \\
\hline In a city & 11.1 \\
\hline In Ljubljana* or Maribor ${ }^{* *}$ & 13.3 \\
\hline \multicolumn{2}{|l|}{ Place of residence } \\
\hline In my house & 72.5 \\
\hline In my apartment & 24.7 \\
\hline In a rented apartment & 2.2 \\
\hline In a rented house & 0.2 \\
\hline In an apartment or house with relatives & 0.1 \\
\hline Other & 0.2 \\
\hline \multicolumn{2}{|l|}{ Household type } \\
\hline Single household & 25.2 \\
\hline Household with partner & 37.2 \\
\hline Household with partner and children & 21.9 \\
\hline Without partner but with children & 5.2 \\
\hline Multigenerational household & 8.6 \\
\hline Other & 1.9 \\
\hline \multicolumn{2}{|l|}{ Residence's adequacy for older people's needs } \\
\hline Yes & 82.0 \\
\hline No & 18.0 \\
\hline \multicolumn{2}{|l|}{ Proximity of relatives } \\
\hline In the same household & 21.1 \\
\hline In the same building, but in another household & 20.1 \\
\hline In the same neighbourhood or in the same area & 27.2 \\
\hline Somewhere else & 30.3 \\
\hline I do not have close relatives & 1.3 \\
\hline \multicolumn{2}{|c|}{$\begin{array}{l}\text { Environment conditions satisfaction (mean; scale } 1-5 ; 1=\text { not satisfied at all, } \\
5=\text { very satisfied) }\end{array}$} \\
\hline General orderliness & 4.17 \\
\hline Peacefulness & 4.27 \\
\hline Air quality & 4.16 \\
\hline Safety & 4.35 \\
\hline
\end{tabular}


Table 1. Cont.

Accessibility satisfaction (mean; scale $1-5 ; 1=$ not satisfied at all,

$5=$ very satisfied)

\begin{tabular}{|c|c|}
\hline Access to the building & 4.32 \\
\hline Access to the home & 4.11 \\
\hline Proximity of relatives and friends & 4.13 \\
\hline Healthcare proximity & 4.12 \\
\hline Access to long-term care & 3.97 \\
\hline Socialisation and recreation opportunities & 4.03 \\
\hline Proximity of public amenities and services & 4.13 \\
\hline \multicolumn{2}{|c|}{$\mathbf{b}$} \\
\hline Variables & Value \\
\hline Age (in years) & 69.4 \\
\hline
\end{tabular}

Home modifications needed (mean; scale $1-5 ; 1=$ no need at all, $5=$ very necessary)

\begin{tabular}{|c|c|}
\hline Bathroom & 2.53 \\
\hline Room distribution & 1.90 \\
\hline Easier and safer movement & 2.21 \\
\hline Easier access to the home & 2.10 \\
\hline Kitchen adaptation & 1.83 \\
\hline Furniture and equipment adaptation & 1.86 \\
\hline \multicolumn{2}{|c|}{ Housing satisfaction (mean; scale $1-5 ; 1=$ not satisfied at all, $5=$ very satisfied) } \\
\hline Room distribution & 4.18 \\
\hline Size & 4.11 \\
\hline Construction quality & 3.94 \\
\hline \multicolumn{2}{|c|}{ Housing value (mean; scale $1-5 ; 1=$ not important at all, $5=$ very important) } \\
\hline Represents a legacy for my children & 3.99 \\
\hline Represents my life achievement & 4.04 \\
\hline Represents a memory of my life & 4.00 \\
\hline Where my friends and acquaintances live & 3.92 \\
\hline I manage well in this home and environment & 4.57 \\
\hline Is a great financial investment & 3.92 \\
\hline I feel independent in this home & 4.70 \\
\hline \multicolumn{2}{|c|}{ Attachment (mean; scale $1-5 ; 1=$ not attached at all, $5=$ very attached) } \\
\hline To the home & 4.38 \\
\hline To environment & 4.20 \\
\hline \multicolumn{2}{|c|}{$\begin{array}{l}\text { Environmental conditions satisfaction (mean; scale } 1-5 ; 1=\text { not satisfied at all, } \\
5=\text { very satisfied) }\end{array}$} \\
\hline General orderliness & 4.17 \\
\hline Peacefulness & 4.27 \\
\hline Air quality & 4.16 \\
\hline Safety & 4.35 \\
\hline
\end{tabular}


Table 1. Cont.

\begin{tabular}{ll}
\hline $\begin{array}{l}\text { Accessibility satisfaction (mean; scale } 1-5 ; 1=\text { not satisfied at all, } \\
5=\text { very satisfied) }\end{array}$ & \\
\hline Access to the building & 4.32 \\
\hline Access to the home & 4.11 \\
\hline Proximity of relatives and friends & 4.13 \\
\hline Healthcare proximity & 4.12 \\
\hline Access to long-term care & 3.97 \\
\hline Socialisation and recreation opportunities & 4.03 \\
\hline Proximity of public amenities and services & 4.13 \\
\hline
\end{tabular}

Notes: Missing values or "I don't know" were excluded. * Ljubljana is the capital of Slovenia (population 280,940);

** Maribor is the second-largest city in Slovenia (population 94,642); Missing values or "I don't know" were excluded.

\subsection{Clustering Procedure}

The dependent variable in the analysis was attitudes toward or the acceptability of living arrangements for older people already established in Slovenia. The options included 1) a care home, 2) supported housing, 3) staying at home with the support of social home-care services and 4) staying at home with daily visits to a daycare centre for older people. The respondents were asked to score the offered living arrangements on a scale from 1 to $5(1=$ totally unacceptable, $2=$ unacceptable, $3=$ neutral, $4=$ acceptable, $5=$ perfectly acceptable).

\subsection{Dependent Variables}

The characteristics of the clusters were investigated regarding the three theoretically grounded dimensions and some additional independent variables (Figure 1). The first dimension was social support, which is presented in the theoretical section. Social support is vital for enabling staying at home [34] and its absence can promote a higher preference for moving if there are higher care needs. The availability of social support was assessed using an objective measure of how close relatives were, and a subjective measure of satisfaction with how close the relatives are was also made (see the detailed description of the questionnaire in the Appendix A).

The second important dimension as defined in the theoretical part was satisfaction with the home and neighbourhood [30]. Housing satisfaction (i.e., satisfaction with characteristics of the home, such as the layout of rooms, size and construction quality and accessibility) was measured separately. Furthermore, modifications needed and satisfaction with the neighbourhood was measured, in which a distinction was made between satisfaction with general characteristics of the neighbourhood (general orderliness, peacefulness, air quality, safety) and satisfaction with services, which are vital for quality ageing in place (such as proximity of healthcare, public amenities and services, access to long-term care, recreation and socialising opportunities).

The third dimension was place attachment, which was measured with commonly used questions regarding how attached people feel to their home and neighbourhood. Questions that examine the meaning of home were also added as an additional level used to understand the source of attachment [35], which the literature shows is linked to the issue of legacy, independence (managing well in the home and feeling independent), life memory (home being understand as life achievement and memory of one past), financial aspects (home as a financial investment) and home as a place of socializing. All these dimensions were observed and respondents graded how important these dimensions were to them (see detailed questions in the Appendix A).

Additional independent variables that were observed included income, age (because preferences for moving decline with age and cohorts may vary in their preferences [54]), gender, health status (because poor health is an important push factor for moving [4-8]) and household type, because 
partners and family members are the most common informal caregivers and therefore enable staying at home even when there are high care needs, whereas single people have more difficulty staying at home.

The correlation of these dependent variables was tested for with an independent variable; for the cluster groups, one-way ANOVA was used for continuous variables and chi-square was used for categorical variables.

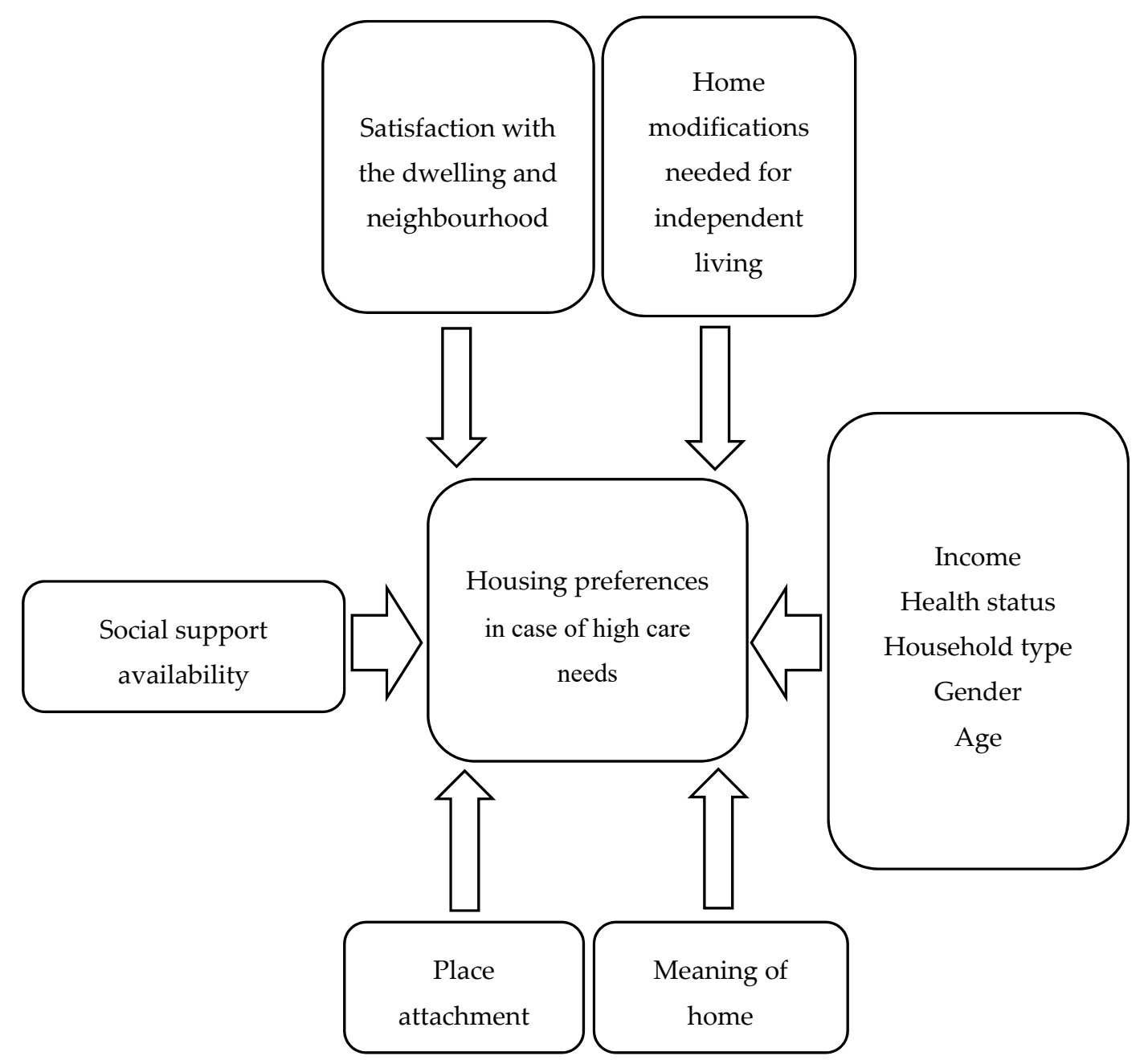

Figure 1. Model of housing preferences if there are high care needs.

\section{Results}

The average acceptability of various housing options is presented in Figure 2. The most acceptable housing choice among respondents was moving into a care home, which scored 3.91. This is the most familiar and most developed option in Slovenia, which explains its high acceptability. Slovenia has a long tradition of eldercare facilities that provide non-profit social-care services. Until 1991, these institutions were a public service, but since the 1992 adoption of the Social Security Act, institutional care service can also be provided by private companies based on a license [57]. Over the last three decades, the number of care homes has thus significantly increased. According to the Slovenian Community of Social Institutions, at the end of 2017, there were 20,718 beds available in 59 public and 41 private homes, which was sufficient for $5.2 \%$ of people aged 65 and over. However, this institutional form of living faces two major problems. Because the accommodation capacities are very limited, waiting lists have been created and a growing proportion of older people will find institutional 
care increasingly difficult to afford due to tightening financial conditions and reduced subsidies for institutional care.

Staying at home with the aid of social home-care services had the same level of acceptability (a score of 3.88, see Figure 2). This second option enables people to stay at home. The literature has demonstrated that this is the preferred living arrangement, and this is also true under the conditions of liminality presented to the respondents, i.e., under conditions of diminished health and where the support of family is not sufficient. Therefore, social home care is one of the key services for ensuring high-quality ageing in place. However, although this option is relatively desirable among older people, it has several shortcomings. The number of users grew from the 1990s until 2009, when it settled at a relatively low level. In 2017, 1.7\% of older people over 65 used this service [58,59]. In addition to this low level, significant geographical differences are also evident in the development of social home-care services (see Hlebec [60]). All of this increases the number of older people in various parts of Slovenia whose needs for care are not being met and who consequently have a lower quality of life; at the same time, this increases the pressure on informal caretakers, especially family members, which also influences their quality of life.

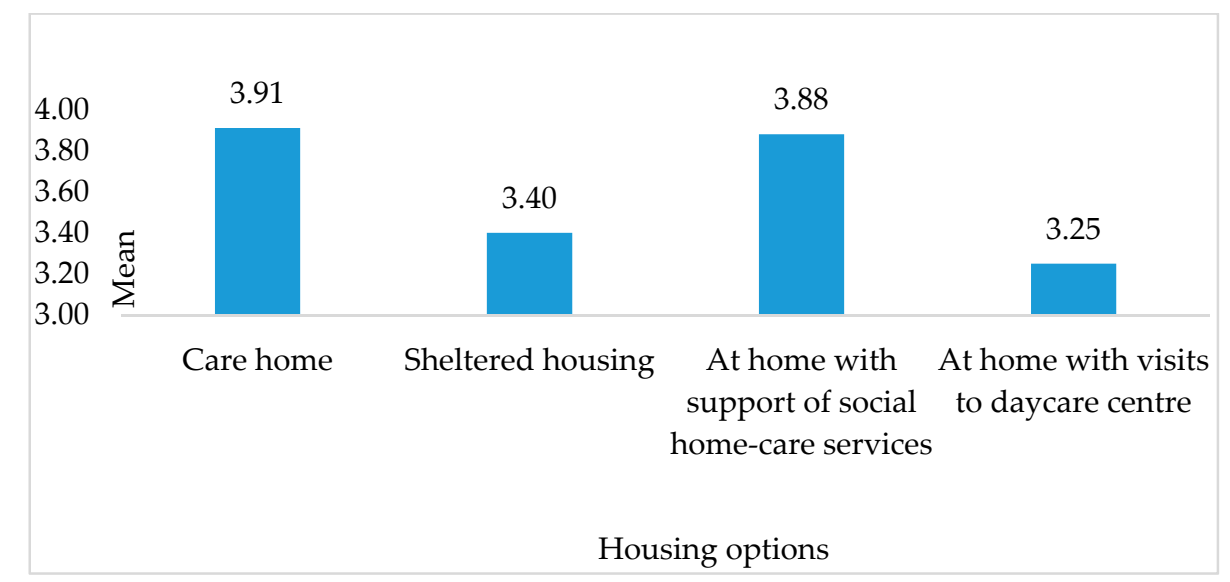

Figure 2. Acceptability of housing options under conditions of high care needs.

The third option was sheltered housing. This had a medium level of acceptability, with a mean score of 3.40. Sheltered housing is architecturally adapted to older people with their own households, usually in a peaceful environment and with 24-hour-a-day optional institutional assistance [61]. This housing option has not been well developed in Slovenia. The primary builders of sheltered housing are the Slovenian Real Estate Fund of Pension and Disability Insurance, municipal housing funds and private investors. However, in 2015, there were 981 sheltered housing units in Slovenia (around 1200 according to estimates in 2019 [62]). Most sheltered housing units are rentals, and some are also available for purchase. However, the problem is that rents and purchase prices are quite expensive and therefore unattainable by the majority of older people. In 2015, for example, only $74 \%$ of capacities in rented sheltered housing units were occupied. The occupancy of owned sheltered housing units was even lower at only $34 \%$ in some areas [62].

The last option offered was staying at home and visiting a local daycare centre, which had an average score of 3.25. This was the least preferred option, and it is also the least familiar and least well-developed option in Slovenia, which might be relevant to its lower preferability. Daycare is yet another service for older people living in their own homes. Most of the providers of this service are homes for older people but they can also be independent institutions. Any older person who does not want to be at home alone during the day (or is not able to be alone) can be included. This service is especially desirable for families whose other members are busy at work during the day [63]. The basic service at daycare centres is transportation to the centre, meals, healthcare, personal hygiene, various forms of counselling, education, entertainment and a place to rest [64]. There were 55 daycare centres 
in Slovenia in 2019, and most of them were part of care homes [65]. Perhaps this is an additional reason for the low preference for this option since it is too linked to the institutionalized setting. This low preference would definitely warrant additional research to understand this reluctance and improve this option.

A cluster analysis was performed based on the acceptability of the four housing options, and the result was five distinct groups of respondents regarding their housing preferences under conditions of high care needs. These groups are also described in relation to their characteristics, such as health, income, sociodemographic variables and the three dimensions that influence choices: 1) availability of an informal support network, 2) satisfaction with the home and neighbourhood and 3) attachment to home. The results of the cluster analysis are presented in Figure 3 and the cluster characteristics are presented in Table 2.

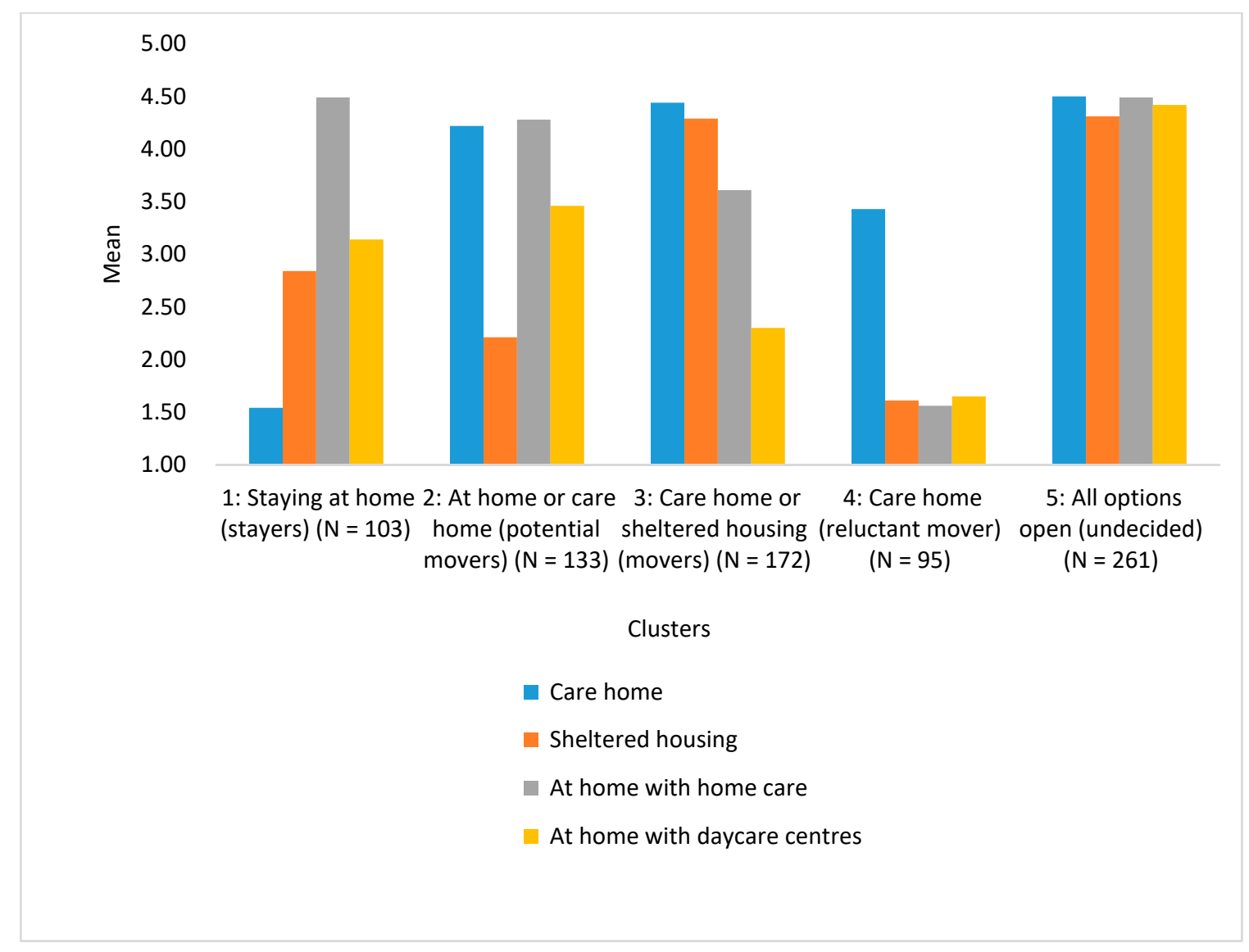

Figure 3. Results of cluster analysis: housing choices.

Table 2. Characteristics of clusters (by dependent variables).

\begin{tabular}{|c|c|c|c|c|c|}
\hline Dependent Variables/Clusters & 1 & 2 & 3 & 4 & 5 \\
\hline Age (mean) $)^{* *}$ & 69.0 & 71.0 & 69.1 & 71.7 & 67.8 \\
\hline Health (mean) ${ }^{* * *}$ & 3.22 & 3.46 & 3.41 & 3.25 & 3.63 \\
\hline Education (\% with higher education) $)^{* *}$ & 18.6 & 18.7 & 33.3 & 17.0 & 28.1 \\
\hline Income (\% with difficulty managing income $)^{* *}$ & 17.6 & 13.6 & 10.6 & 25.3 & 9.1 \\
\hline Household type ( $\%$ of single households) ${ }^{* *}$ & 26.5 & 32.6 & 16.5 & 40.0 & 21.3 \\
\hline Relocation ( $\%$ considering moving house) ${ }^{* * *}$ & 15.5 & 9.0 & 25.6 & 5.3 & 14.2 \\
\hline Relatives living further away (\%) & 21.0 & 32.3 & 36.4 & 41.9 & 27.7 \\
\hline
\end{tabular}


Table 2. Cont.

\begin{tabular}{|c|c|c|c|c|c|}
\hline Dependent Variables/Clusters & 1 & 2 & 3 & 4 & 5 \\
\hline \multicolumn{6}{|l|}{ Satisfaction with ... (mean) } \\
\hline Room distribution & 4.26 & 4.22 & 4.06 & 4.15 & 4.21 \\
\hline Building quality & 3.80 & 4.01 & 3.85 & 3.97 & 4.00 \\
\hline Size & 4.11 & 4.05 & 3.99 & 4.12 & 4.21 \\
\hline General orderliness ${ }^{* *}$ & 4.10 & 4.23 & 4.07 & 4.38 & 4.10 \\
\hline Peacefulness of environment & 4.32 & 4.31 & 4.24 & 4.35 & 4.22 \\
\hline Air quality & 4.28 & 4.11 & 4.13 & 4.36 & 4.17 \\
\hline Safety & 4.43 & 4.40 & 4.29 & 4.33 & 4.38 \\
\hline \multicolumn{6}{|l|}{ Home modifications needed (mean) } \\
\hline Bathroom & 2.60 & 2.69 & 2.57 & 2.33 & 2.60 \\
\hline Room distribution ${ }^{* *}$ & 1.94 & 2.11 & 2.01 & 1.73 & 1.82 \\
\hline Easier and safer movement & 2.25 & 2.39 & 2.28 & 1.99 & 2.20 \\
\hline Easier access to the home ${ }^{* *}$ & 2.14 & 2.29 & 2.28 & 1.73 & 2.17 \\
\hline Kitchen adaptation & 1.80 & 1.98 & 1.87 & 1.69 & 1.82 \\
\hline Furniture and equipment adaptation & 1.86 & 2.02 & 1.91 & 1.72 & 1.85 \\
\hline \multicolumn{6}{|l|}{ Accessibility (mean) } \\
\hline Accessibility to the building & 4.36 & 4.39 & 4.23 & 4.29 & 4.34 \\
\hline Access to the home & 4.14 & 4.11 & 3.94 & 4.09 & 4.20 \\
\hline Proximity of family and friends & 4.23 & 4.23 & 4.01 & 4.08 & 4.18 \\
\hline Proximity of healthcare services & 4.16 & 4.26 & 4.03 & 4.08 & 4.15 \\
\hline Access to long-term care ${ }^{* *}$ & 3.86 & 4.01 & 3.88 & 3.90 & 4.12 \\
\hline Socialisation and recreation opportunities & 3.90 & 4.11 & 3.94 & 3.90 & 4.14 \\
\hline Proximity of public amenities and services & 4.06 & 4.16 & 4.00 & 4.22 & 4.22 \\
\hline \multicolumn{6}{|l|}{ Meaning of home (mean) } \\
\hline Legacy for my children*** & 4.08 & 4.23 & 3.67 & 3.99 & 4.05 \\
\hline My life achievement*** & 4.12 & 4.24 & 3.76 & 4.16 & 4.10 \\
\hline Represents a memory of my life $\mathrm{e}^{* * *}$ & 4.25 & 4.27 & 3.55 & 4.18 & 4.18 \\
\hline Where my friends and acquaintance live $\mathrm{e}^{* * *}$ & 3.93 & 4.06 & 3.63 & 3.97 & 4.10 \\
\hline Manage well in the home and environment ${ }^{* * *}$ & 4.68 & 4.68 & 4.42 & 4.51 & 4.61 \\
\hline A great financial investment ${ }^{* * *}$ & 4.17 & 3.92 & 3.68 & 3.85 & 4.03 \\
\hline I feel independent in this home & 4.78 & 4.71 & 4.62 & 4.69 & 4.74 \\
\hline \multicolumn{6}{|l|}{ Attachment (mean) } \\
\hline To the home $e^{* * *}$ & 4.51 & 4.55 & 4.11 & 4.47 & 4.41 \\
\hline To the environment ${ }^{* * *}$ & 4.38 & 4.37 & 3.90 & 4.45 & 4.18 \\
\hline
\end{tabular}

Note: ${ }^{* * *} p \leq 0.001,{ }^{* *} p \leq 0.05$.

In the first group were those who prefered staying at home. They had a very low preference for care homes with by far the lowest evaluation of this option (score: 1.54) among all the groups. A characteristic of this group was that they were more likely to have relatives living nearby (in the same building or neighbourhood). They were the group that were most satisfied with the proximity of family and friends, safety and proximity of health care. This group was also the most satisfied with the 
distribution of rooms in their homes. Older people in this group felt independent and got along well in their homes and in their environment. Attachment to place was very high. A specific feature of this group was also that the respondents in it had the poorest health of any of the groups.

The second group included those who expressed a preference for either staying at home or going into a care home. Within this group, there was a higher share of respondents who lived in single households. They were older than average but healthier. The respondents in this group evaluated accessibility more favourably than the average, and accessibility to the building they lived in was the highest among all groups. They were also the most satisfied with the construction quality of the building they lived in, and they considered that modifications of the home were needed for living in later life (the share of those demonstrating this variable was higher than in the other groups). Attachment to home and seeing it as an important achievement in life, as well as part of a memory in life, was also very high in this group. This seems to be the group that would like to stay at home as long as possible; however, due to the greater remoteness of relatives and the need for modifications to the home, they also considered moving into a care home to be a possibility.

The third group included those who preferred a care home or sheltered housing. Relatively high incomes and levels of education were characteristics of this group, which confirmed that sheltered housing was an accessible option for people with a higher income. Therefore, this was one of the two groups for which moving during conditions of high care needs was preferred to staying at home. This linked to the characteristics of the groups that were in line with the theoretical presumptions of the impact of attachment and housing satisfaction. This group was characterised by relatively low satisfaction with their homes and their surroundings. Especially important was the lower satisfaction with access to long-term care services in the locality, and with this, the availability of formal support that would make it possible to remain at home. The meaning of home and attachment to place was also the lowest among all the groups. Therefore, this seems to be the group that, due to dissatisfaction with services in the environment and lower attachment, will be more likely to move in the case of increased needs. This was also the group for which the share of those who considered moving was the highest, and also for which the share of those with relatives living further away was high.

The fourth group was the smallest among all the groups. The members of this group saw a care home as the only possible option. Even though this option was not highly acceptable-it scored below average (at 3.43), which was the second-lowest acceptability among all groups for this option (the lowest being in the group preferring to staying at home)—all the other options scored less than 1.7 and were therefore highly unacceptable. Therefore, it seems that among poor choices, a care home was the least poor option. This was the group with the lowest share of those who had so far thought about relocating. They liked their environment and they were the most attached to it among all groups. However, this was the oldest group, with poor health. It had the highest share of those who had difficulty managing on their income, and also the highest share of those living in single households and of family members living further away. Therefore, under conditions of a poor support network and poorer health, they saw a care home as the only possibility, which they did not find highly acceptable, but as a necessary choice. This was probably also why they did not see the need to rearrange their homes (the average need for modifications was the lowest among all groups).

The fifth group was the largest, and it included people who were open to all housing options and positively evaluated all possibilities. They were the youngest, the healthiest and the best educated. For them, the options referred to might have seemed more distant than to the other groups, and therefore potentially less realistic. Their attitudes might have yet to form as they become older, and as the health and care needs that the question referred to increase. This was also the group with the highest income, which might also be an important determinant of the accessibility of all the proposed choices, especially sheltered housing. 


\section{Discussion}

The results presented illustrate the complexity of the decision-making process under imagined conditions of liminality, i.e., the high care needs of older people. It showed a great diversity among people regarding the acceptability of different housing options and of the choice between staying at home, moving into a care home or moving into sheltered housing. An important part of the sample (i.e., two groups, which corresponded to a quarter of the sample) seemed to have only one choice and expressed only one preference strongly. The majority of the groups saw more options as being possible, which depended on their income, availability of kin and satisfaction with housing, and more specifically, services in the environment and attachment to home. All three dimensions-attachment to place, residential satisfaction and the availability of support (see Figure 4)-were therefore linked with decisions to stay or move under conditions of poorer health. In particular, attachment to place and residential satisfaction proved to be very important. According to Löfqvist et al. [13], this is one of the reasons older people often resist relocating, even when they are unable to maintain their quality of life. In this study, the first and second groups, which among all the options, rated staying at home the highest, also expressed the highest level of satisfaction and attachment among all groups, especially an attachment to the home. All aspects of the importance of housing were assessed by these two groups with the highest scores, or at least above average. In particular, scores for managing well in the home and environment stand out. On the other hand, the third group, which evaluated the acceptability of relocation very highly and had the highest share of those thinking about moving, expressed the lowest degree of place attachment and satisfaction. Furthermore, among all groups, the third group had the lowest values of all factors that referred to place attachment and satisfaction, as well as the importance of home. This is another indicator of the fact that place attachment and residential satisfaction had a significant impact on the decision to relocate or to stay at home under the conditions of hypothetical liminality. The findings were therefore consistent with the findings of other researchers on the relevance of attachment in old age regarding the decision to move or stay $[13,46]$.

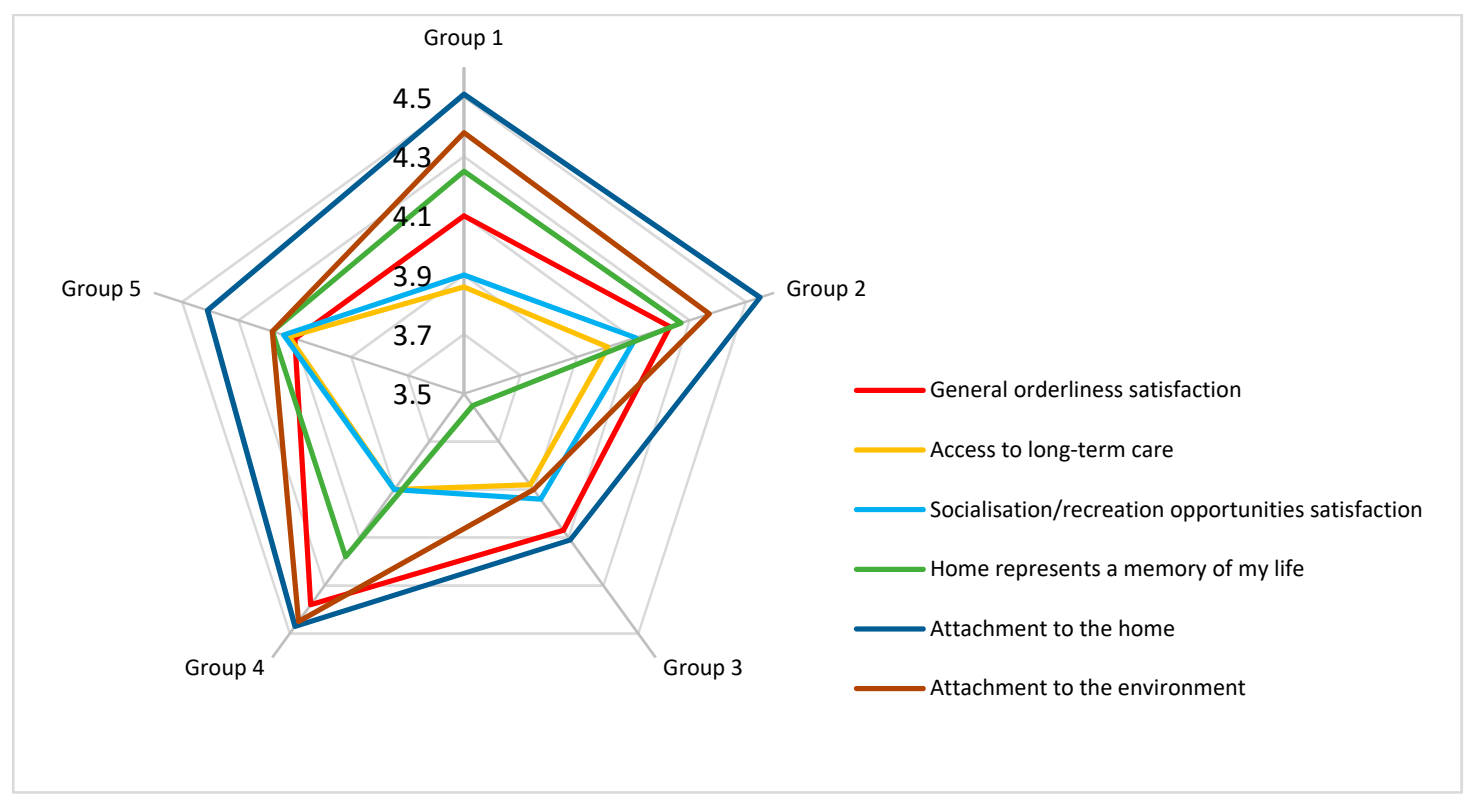

Figure 4. Selected variables linked with cluster groups of older people differentiated by their housing preferences in the case of poor health. Note: Group 1-stayers (staying at home); group 2-potential movers (at home or care home); group 3-movers (care home or sheltered housing); group 4-reluctant mover (care home); group 5-undecided (all options open)

For example, Farber et al. [25] observed that older adults try to live independently in their current residence or community for as long as possible. However, many events, conditions and anticipated 
changes force older people to re-evaluate their place attachment and reconsider whether to stay at home or relocate. Among the three dimensions that were assumed to influence the decision to stay or move, the availability of support is the condition that forces older people to re-evaluate their place attachment and satisfaction and that influences their ability to continue living independently (see Davey et al. [66]). This was also confirmed by Heap [67], who found that older people relate their notion of satisfaction and commitment to housing with care that enables them to live independently. Lien [68] claimed that the reality of ageing typically includes the need for reliable and permanent care, as well as emotional and physical support. Kubalčíková and Havlíková [69] also emphasised home care, especially informal care, as one of the most important factors that help older people age at home. In the study, the fourth group showed the highest environmental attachment among all groups, and also a high level of satisfaction with all environmental factors, but the decision to move in the case of high care needs was preferred. Nevertheless, it is interesting that those in the fourth group considered moving the least among all groups. This confirms the findings of Fernández-Carro [29], who stated that many older people remain in a state of "in between-ness" in their homes, and they also want to remain in their homes in the future until their functional autonomy and health status conditions force them to move into a nursing institution. Among all groups, the fourth group even expressed above-average satisfaction with public amenities and the proximity of services, but the proximity of services was not enough. A decision to stay at home requires support, specifically the support of relatives. Therefore, the need for relocation had already been clear to those in the fourth group, who were the oldest and least healthy, were most likely to live alone, and had relatives further away. Furthermore, those in the fourth group did not want to think about relocation but they were aware that without the support of family caregivers, they did not have another option. The role of the family as a care provider for older family members is particularly important in countries where formal social home care and other support services for older people (i.e., daycare centres) are poorly represented or used (like Slovenia, or elsewhere in central and eastern Europe (see References [70,71])).

Therefore, the findings related to the preferences and housing choices in old age confirm the complexity of these processes (see References [13,72]). However, what is interesting is the fact that the groups were not at all distinguished by different residential locations, i.e., in cities, suburbs or the countryside. Here, we expected to find differences because a survey on the social exclusion of older people (see Filipovič Hrast [73]) showed that, compared to other EU countries, Slovenia had a significantly higher share of older people who are spatially excluded, i.e., who do not have access to basic services in their home environments, which is the key obstacle to high-quality ageing in place and increases the dependence of older people, and that there is a high regional diversity in the accessibility of social home-care services [60]. However, the study identified no differences in older people's housing preferences in terms of whether they lived in rural or urban settlements. It seems that despite proven spatial exclusion, the countryside is turning into a very heterogeneous place influenced by urbanisation processes, which also affects the attitudes of its older inhabitants (see Kerbler et al. [74]). Here, more detailed research is needed to distinguish between lower levels of spatial organisation, such as the specifics of a neighbourhood, which are an important facilitator for ageing in place (see Dahlberg [75]).

Following the results, other very important findings emerged that are related to homeownership. The post-communist countries of central and eastern Europe (among them Slovenia) are characterised by very high levels of homeownership [17]. As stated by Sendi et al. [76], homeownership can be an important financial asset under the condition of increasing care costs and withdrawal of the welfare state. The results of this study showed that all groups except one (the first group) would have the use of this financial asset while enacting their potential option of moving. What is worrying is that this was the most likely choice among the higher-income households (groups three and five), but a more reluctant or delayed choice in the other groups (groups two and four). Group two's members had a choice between staying or moving to a care home but because they valued the home as a legacy for the children the most, it was less likely that they will use this financial asset to fund their care needs. The same was also expected from the fourth group, for which home as a life achievement was very highly 
scored. This has important policy implications and efforts will have to be made to raise awareness among older people in central and eastern Europe regarding knowledge that their homeownership can be an important financial asset under conditions of high care needs. As found by Mandič [77] (pp. 165), a significant role of the family in the case of old-age care could be supported by housing wealth and would help to "bridge the post-transitional old-age gap, the syndrome of low pensions, underdeveloped care services and owner-occupied housing".

\section{Conclusions}

This study analysed the future housing choices of a cohort aged 50 and over in a specific position of hypothetical liminality, in this case observed as specific high care needs, and their housing preferences in these conditions. The results presented illustrate the complexity of the decision-making process and indicated a great diversity among people regarding the acceptability of different housing options, with a quarter of respondents not stating any choice but instead showing a strong preference for only one option, whereas others had more diverse ratings of preferences. The choices between relocation and staying at home, as well as between different variants of care provision, were linked to the availability of relatives, satisfaction at home and attachment to place, which is in line with the literature. However, this study added another level of depth to these findings, showing how the decisions and preferences were formed in different relations to all three observed dimensions of influence on housing choice in later life. The distinct choices and preferences expressed by the five different groups of older people show how people navigate between the constraints of the environment and their immediate housing, their care needs and the availability of support.

The study has important policy implications. Post-communist central and eastern European counties like Slovenia should (continue to) develop various housing options for older people. This is not only needed due to the accelerated ageing of the population, but also because of the younger generations of older people who are open to various housing opportunities in old age, as this study indicated (see also Filipovič Hrast et al. [20]). Because older people are mostly attached to their home environment and satisfied with it, priority should be given to ageing in place and to ensuring that older people can remain in their home environment for as long as possible. Different forms of home support services should be provided for this purpose, and special attention should be given by developers to the daycare centres, which at the moment, seem to be the least preferred option, although they enable staying in the home environment. Special attention and further research is therefore needed to understand the reluctance and improve the service to make it more acceptable to older people. Furthermore, support for informal carers is a vital part of the housing choice for older people. Family care constitutes a significant share of eldercare in all European countries, including post-communist central and eastern European counties (e.g., Slovenia), which are described as familialistic care regimes (see References [18,19]), i.e., they emphasise and value family care [70,71,78]. However, dependence on family care entails a higher burden for family carers (see References [79,80]), in particular female carers, who represent the largest share of family carers [81,82]. Changing family forms, extended working lives and the difficulty of combining work and care introduce additional challenges to the provision of informal family care; therefore, this calls for developing policies to support such care, which is a vital part of the decision-making process for staying or moving in old age.

The study has important limitations. An important limitation of the study is the fact that what was measured were potential choices and not actual decisions regarding care. The actual decisions are based on the constraints observed above but also unexpected life events and other factors, the observation of which was limited in the current model of the study (see References $[72,83,84])$. Therefore, longitudinal methods that would enable observing changes in preferences and their formation through various life events would enable a better understanding of how housing preferences (as formed and observed in hypothetical situations) evolve and change over time. In addition, housing preferences and choices in cases of liminality are often made not solely by the individuals, but most often in caring dyads, and 
therefore, the housing preferences and choices not only of the older people but also of their (potential) carers should be observed.

Author Contributions: Conceptualization, M.F.H.; funding acquisition, B.K.; writing—original draft, M.F.H., B.K., and R.S. All authors have read and agreed to the published version of the manuscript.

Funding: The research was financially supported by ARRS (Javna Agencija za Raziskovalno Dejavnost RS), grant numbers J5-6824, J5-8243 and P5-0200.

Acknowledgments: The authors are grateful to M.M. and K.S. for their technical assistance, and to D.F.R. for providing language help, writing assistance and proofreading.

Conflicts of Interest: The authors declare no conflict of interest.

\section{Appendix A}

\section{A.1. Social Support Availability}

This dimension was investigated with the following questions:

"Where do your closest relatives live?" Response options: 1. In the same household, 2. In the same house, but not the same household, 3. In the same neighbourhood/area, 4. Elsewhere, 5. I do not have close relatives.

"How satisfied are you with how close your relatives live?" (Response options were on a scale of $1=$ not satisfied at all to $5=$ very satisfied)

\section{A.2. Satisfaction with the Dwelling and Neighbourhood}

"How satisfied are you with the following?" (Response options were on a scale of $1=$ not satisfied at all to $5=$ very satisfied)

Satisfaction with characteristics of the dwelling (layout of rooms, size and construction quality);

Satisfaction with access to the dwelling (access to the residential building, apartment);

Satisfaction with the neighbourhood (general orderliness, peacefulness, air quality, safety);

Satisfaction with services (proximity of healthcare, public amenities and services, access to long-term care, recreation and socialising opportunities).

"Which modifications are needed in your dwelling for independent living in old age?" (Response options were on a scale of $1=$ not needed at all to $5=$ very necessary)

Bathroom and toilet modifications

Changes in the layout of the premises

Rearrangements for easier and safe movement

Rearrangements for easier access to the dwelling

Modifications in the kitchen

Modifications to furniture and equipment

\section{A.3. Place Attachment}

Place attachment was measured with the following questions:

"How attached are you to your home?"

"How attached are you to your neighbourhood/locality?"

(Response options were on a scale from $1=$ not at all attached, to $5=$ very attached).

The meaning of home was measured by how important the following statements were (Response options were on a scale of $1=$ not important at all to $5=$ very important):

The dwelling represents a legacy for my children;

The dwelling represents my life achievement; 
The dwelling represents a memory of my life;

This is where my friends and acquaintances live;

I manage well in this dwelling and environment;

The dwelling is a great financial investment;

I feel independent in this dwelling.

\section{A.4. Additional Variables Observed Were:}

Income level: "How easily can you manage on your current income?" (Response options 1 . We can manage easily with our current income, 2 . We can manage, 3 . It is hard to manage on the current income, 4 . It is very hard to manage on the current income);

Health status: "How would you rate your health on a scale of 1 (very bad) to 5 (very good)?" and "Are you limited in everyday life by any chronic diseases or handicaps?" (Response options 1 . Yes, to a larger degree, 2. Yes, to a smaller degree, 3. No);

Household type (single vs. other types);

Gender;

Age.

\section{References}

1. Eurostat. People in the EU-Population Projections; Eurostat: Brussels, Belgium, 2015; Available online: http://ec.europa.eu/eurostat/statistics-explained/index.php/People_in_the_EU_\%E2\%80\%93_population_ projections (accessed on 20 January 2017).

2. Van Vliet, W. The Encyclopedia of Housing; Sage: Thousand Oaks, CA, USA, 1998.

3. Robinson, J.; Moen, P. A life-course perspective on housing expectations and shifts in late life. Res. Aging 2000, 22, 499-532. [CrossRef]

4. Longino, C.F.; Smith, K.J. Black retirement migration in the United States. J. Gerontol. Soc. Sci. 1991, 46, 125-132. [CrossRef] [PubMed]

5. Reshovsky, J.D.; Newman, S.J. Adaptations for independent living by older frail households. Gerontologist 1990, 30, 543-552. [CrossRef] [PubMed]

6. Rogers, A. Return migration to region of birth among retirement-age persons in the United States. J. Gerontol. Soc. Sci. 1990, 45, 128-134. [CrossRef]

7. Speare, A.; Avery, R.; Lawton, L. Disability, residential mobility, and changes in living arrangements. J. Gerontol. Soc. Sci. 1991, 46, 133-142. [CrossRef]

8. Sabia, J.J. There's no place like home: A hazard model analysis of aging in place among older homeowners in the PSID. Res. Aging 2008, 30, 3-35. [CrossRef]

9. Kerbler, B. Ageing at home with the help of information and communication technologies. Acta Geogr. Slov. 2012, 52, 165-188. [CrossRef]

10. Leibing, A.; Guberman, N.; Wiles, J. Liminal homes: Older people, loss of capacities, and the present future of living spaces. J. Aging Stud. 2016, 37, 10-19. [CrossRef]

11. Stones, D.; Gullifer, J. "At home it's just so much easier to be yourself": Older adults' perceptions of ageing in place. Ageing Soc. 2016, 36, 449-481. [CrossRef]

12. Minney, M.J.; Hons, B.A.; Ranzijn, R. We had a beautiful home ... but I think I'm happier here: A good or better life in residential aged care. Gerontologist 2016, 56, 919-927. [CrossRef]

13. Löfqvist, C.; Granbom, M.; Himmelsbach, I.; Oswald, F.; Haak, M. Voices on relocation and aging in place in very old age-A complex and ambivalent matter. Gerontologist 2013, 53, 919-927. [CrossRef] [PubMed]

14. Frank, J. The Paradox of Aging in Place in Assisted Living; Bergin \& Garvey: Westport, CT, USA, 2002.

15. Turner, V.W. The Ritual Process; Cornell University Press: Ithaca, NY, USA, 1977.

16. Grenier, A. Transitions and the Lifecourse: Challenging the Constructions of "Growing Old"; The Policy Press: Bristol, UK, 2012.

17. Tosics, I.; Hegedus, J. Housing in south-eastern Europe. In Housing Change in East and Central Europe: Integration or Fragmentation? Lowe, S., Tsenkova, S., Eds.; Ashgate: Aldershot, UK, 2003; pp. 21-44. 
18. Saraceno, C.; Keck, W. Can we identify intergenerational policy regimes in Europe? Eur. Soc. 2010, 12, 675-696. [CrossRef]

19. Leitner, S. Varieties of familialism. Eur. Soc. 2003, 5, 353-375. [CrossRef]

20. Filipovič Hrast, M.; Sendi, R.; Hlebec, V.; Kerbler, B. Moving house and housing preferences in older age in Slovenia. Hous. Theory Soc. 2019, 36, 76-91. [CrossRef]

21. Mali, J. Od Hiralnic do Domov za Stare Ljudi; Fakulteta za socialno delo: Ljubljana, Slovenia, 2008.

22. Hlebec, V.; Rakar, T. Aging policies in Slovenia: Before and after "austerity". In Selected Contemporary Challenges of Ageing Policy; Tomczyk, Ł., Klimczuk, A., Eds.; Uniwersytet Pedagogiczny w Krakowie: Kraków, Poland, 2017; pp. 27-52.

23. Clark, W.A.; Davies, S. Elderly mobility and mobility outcomes. Res. Aging 1990, 12, 430-462. [CrossRef] [PubMed]

24. Hidalgo, C.; Hernandez, B. Place attachment: Conceptual and empirical questions. J. Environ. Psychol. 2001, 21, 273-281. [CrossRef]

25. Farber, N.; Shinkle, D.; Lynott, J.; Fox-Grage, W. Aging in Place: A State Survey of Livability Policies and Practices: Research Report; AARP Public Policy Institute: Washington, DC, USA, 2011.

26. Clough, R.; Leamy, M.; Miller, V.; Bright, L. Housing Decisions in Later Life; Palgrave Macmillan: New York, NY, USA, 2004.

27. Costa-Font, J.; Elvira, D.; Mascarilla-Miro, O. Ageing in place? Exploring elderly people's housing preferences in Spain. Urban Stud. 2009, 46, 295-316. [CrossRef]

28. Andersson, E.; Abramsson, M. Changing residential mobility rates of older people in Sweden. Ageing Soc. 2011, 32, 963-982. [CrossRef]

29. Fernández-Carro, C. "Ageing in Place" in Europe: A Multidimensional Approach to Independent Living in Later Life. Ph.D. Thesis, Departament de Geografia, Universitat Autònoma de Barcelona, Barcelona, Spain, 2013.

30. Hillcoat-Nallétamby, S.; Ogg, J. Moving beyond "ageing in place": Older people's dislikes about their home and neighbourhood environments as a motive for wishing to move. Ageing Soc. 2014, 34, 1771-1796. [CrossRef]

31. Lawton, M.P. The functional assessment of elderly people. J. Am. Geriatr. Soc. 1971, 19, 465-481. [CrossRef]

32. Lawton, M.P.; Nahemow, L. Ecology and the aging process. In The Psychology of Adult Development and Aging; Eisdorfer, C., Powell Lawton, M., Eds.; The American Psychological Association: Washington, DC, USA, 1973; pp. 619-674.

33. Wiseman, R.F. Why older people move. Res. Aging 1980, 2, 141-154. [CrossRef]

34. Perry, T.E.; Andersen, T.C.; Kaplan, D.B. Relocation remembered: Perspectives on senior transitions in the living environment. Gerontologist 2014, 54, 75-81. [CrossRef] [PubMed]

35. Woodbridge, S. Coping with change: Comparing the retirement housing decisions of older people. In Social Change in the 21st Century; Bradley, R., Lyddon, J., Buys, L., Eds.; QUT: Brisbane, Australian, 2003; pp. 1-13.

36. Giuliani, M.V. Theory of Attachment and Place Attachment. In Psychological Theories for Environmental Issues; Bonnes, M., Lee, T., Bonaiuto, M., Eds.; Ashgate: Aldershot, UK, 2003; pp. 137-170.

37. Feldman, R.M. Settlement-identity psychological bonds with home places in a mobile society. Environ. Behav. 1990, 22, 183-229. [CrossRef]

38. De Jong, P.; Rouwendal, J.; Van Hattum, P.; Brouwer, A. Housing preferences of an ageing population: Investigation in the diversity among Dutch older adults. Netspar Discuss. Pap. 2012. [CrossRef]

39. Phillips, J.; Walford, N.; Hockey, A. How do unfamiliar environments convey meaning to older people? Urban dimensions of placelessness and attachment. Int. J. Ageing Later Life 2012, 6, 73-102. [CrossRef]

40. Wiles, J.L.; Leibing, A.; Guberman, N.; Reeve, J.; Allen, R.E.S. The meaning of "aging in place" to older people. Gerontologist 2011, 52, 357-366. [CrossRef]

41. Dupuis, A.; Thorns, C.D. Meanings of home for older homeowners. Hous. Stud. 1996, 11, 485-501. [CrossRef]

42. Oswald, F.; Wahl, H.W. Dimensions of the meaning of home in later life. In Home and Identity in Late Life: International Perspectives; Rowles, G.D., Chaudhury, H., Eds.; Springer: New York, NY, USA, 2005; pp. 21-46.

43. Dahlin-Ivanoff, S.; Haak, M.; Fänge, A.; Iwarsson, S. The multiple meaning of home as experienced by very old Swedish people. Scand. J. Occup. Ther. 2007, 14, 25-32. [CrossRef]

44. Vasara, P. Not ageing in place: Negotiating meanings of residency in age-related housing. J. Aging Stud. 2015, 35, 55-64. [CrossRef] 
45. Lawton, M.P. Behavior-relevant ecological factors. In Social Structure and Aging: Psychological Processes; Schaie, K.W., Schooler, C., Eds.; Lawrence Erlbaum Associates Inc.: Hillsdale, NJ, USA, 1989; pp. 57-78.

46. Low, S.M.; Altman, I. Place Attachment; Plenum Press: New York, NY, USA, 1992.

47. Bevan, M. Planning for an ageing population in rural England: The place of housing design. Plan. Pract. Res. 2009, 24, 233-249. [CrossRef]

48. Lawton, M.P. Competence, environmental press, and the adaptation of older people. In Aging and the Environment: Theoretical Approaches; Lawton, M.P., Windley, P.G., Byerts, T.O., Eds.; Springer: New York, NY, USA, 1982; pp. 33-59.

49. Kahana, E.; Lovegreen, L.; Kahana, B.; Kahana, M. A person, environment, and person-environment fit as influences on the residential satisfaction of elders. Environ. Behav. 2003, 33, 434-453. [CrossRef]

50. Yun, H. Environmental Factors Associated with Older Adult's Walking Behaviors: A Systematic Review of Quantitative Studies. Sustainability 2019, 11, 3253. [CrossRef]

51. Gong, M.; Ren, M.; Dai, Q.; Luo, X. Aging-Suitability of Urban Waterfront Open Spaces in Gongchen Bridge Section of the Grand Canal. Sustainability 2019, 11, 6095. [CrossRef]

52. Hansen, E.B.; Gottschalk, G. What makes older people consider moving house and what makes them move? Hous. Theory Soc. 2006, 23, 34-54. [CrossRef]

53. Sarma, S.; Simpson, W. A panel multinomial logit analysis of elderly living arrangements: Evidence from aging in Manitoba longitudinal data, Canada. Soc. Sci. Med. 2007, 65, 2539-2552. [CrossRef] [PubMed]

54. Gaymu, J.; Delbès, C.; Springer, S.; Binet, A.; Désesquelles, A.; Kalogirou, S.; Ziegler, U. Determinants of the living arrangements of older people in Europe. Eur. J. Popul. 2006, 22, 241-262. [CrossRef]

55. Longino, C.F.; Bradley, D.E. Internal and international migration. In Handbook of Aging and the Social Sciences; Binstock, R.H., George, L.K., Eds.; Elsevier: San Diego, CA, USA, 2006; pp. 76-93.

56. Kramer, C.; Pfaffenbach, C. Persistence Preferred-on Future Residential (im)mobility among the Generation 50plus. Erdkunde 2009, 63, 161-172. [CrossRef]

57. Kerbler, B. Housing for the elderly in Slovenia: Analysis of the most common forms. Theor. Empir. Res. Urban Manag. 2014, 9, 87-103.

58. Nagode, M.; Lebar, L.; Krejan, P.J. Izvajanje Pomoči na Domu: Analiza Stanja v Letu 2013; Social Protection Institute of the Republic of Slovenia: Ljubljana, Slovenia, 2014.

59. Nagode, M.; Lebar, L.; Ramović, S.; Vidrih, N.; Kobal Tomc, B. Izvajanje Pomoči na Domu: Analiza Stanja v Letu 2017; Social Protection Institute of the Republic of Slovenia: Ljubljana, Slovenia, 2018.

60. Hlebec, V. Individual and contextual determinants of social homecare usage in Slovenia. Zdr. Varst. 2014, 53, 311-317.

61. Real Estate Fund of Pension and Disability Insurance; Ljubljana, Slovenia, 2019. Available online: https: //www.ns-piz.si/si/ (accessed on 8 August 2019).

62. Nagode, M.; Kovač, N.; Lebar, L. Analiza Organiziranosti in Izvajanja Oskrbe na Področju Oskrbovanih Stanovanj: Končno Poročilo; Social Protection Institute of the Republic of Slovenia: Ljubljana, Slovenia, 2015.

63. Sendi, R.; Černič Mali, B.; Jakoš, A.; Filipović, M. Stanovanjske Potrebe Upokojencev in Drugih Starejših Ljudi; Urban Planning Institute of the Republic of Slovenia: Ljubljana, Slovenia, 2003.

64. Grdiša, R. Priročnik za Načrtovanje Sodobnih Oblik Bivanja za Stare Ljudi; University of Ljubljana, Faculty of Architecture Ljubljana: Ljubljana, Slovenia, 2010.

65. Safety Ageing. Seznam Dnevnih Centrov za Starejše. Portal Varna Starost. 2019. Available online: http://varnastarost.si (accessed on 8 August 2019).

66. Davey, J.; Nana, G.; de Joux, V.; Arcus, M. Accommodation Options for Older People in Aotearoa/New Zealand; New Zealand Institute for Research on Ageing/Business \& Economic Research Ltd, Centre for Housing Research Aotearoa: Wellington, New Zealand, 2004.

67. Heap, J. Living Conditions in Old Age: Coexisting Disadvantages across Life Domains; Department of Social Work, Stockholm University: Stockholm, Sweden, 2016.

68. Lien, L.L. Home as identity: Place-making and its implications in the built environment of older persons. Hous. Soc. 2009, 36, 149-170. [CrossRef]

69. Kubalčíková, K.; Havlíková, J. The potential of domiciliary care service in the Czech Republic to promote ageing in place. Eur. J. Soc. Work 2015, 18, 65-80. [CrossRef]

70. Fenger, H.M. Welfare regimes in central and eastern Europe: Incorporating post-communist countries in a welfare regime typology. Contemp. Issues Ideas Soc. Sci. 2007, 3, 1-30. 
71. Zigante, V. Informal Care in Europe. Exploring Formalisation, Availability and Quality; European Commission: Brussels, Belgium, 2018.

72. Granbom, M.; Himmelsbach, I.; Haak, M.; Löfqvist, C.; Oswald, F.; Iwarsson, S. Residential normalcy and environmental experiences of very old people: Changes in residential reasoning over time. J. Aging Stud. 2014, 29, 9-19. [CrossRef] [PubMed]

73. Filipovič Hrast, M. Socialna izključenost starejših. In Blaginja pod Pritiski Demografskih Sprememb; Mandič, S., Filipovič Hrast, M., Eds.; Faculty of Social Sciences: Ljubljana, Slovenia, 2011; pp. 79-82.

74. Kerbler, B.; Sendi, R.; Filipovič Hrast, M. The relationship of the elderly toward their home and living environment. Urbani Izziv 2017, 28, 96-109. [CrossRef]

75. Dahlberg, L. Ageing in a changing place: A qualitative study of neighbourhood exclusion. Ageing Soc. 2019, 1-19. [CrossRef]

76. Sendi, R.; Filipovič Hrast, M.; Kerbler, B. Asset-based welfare: Is housing equity release a viable option for pensioners in Slovenia. J. Eur. Soc. Policy 2019, 29, 577-589. [CrossRef]

77. Mandič, S. Housing for care: A response to the post-transitional old-age gap? J. Eur. Soc. Policy 2016, 26, 155-167. [CrossRef]

78. Bettio, F.; Plantenga, J. Comparing care regimes in Europe. Fem. Econ. 2004, 10, 85-113. [CrossRef]

79. Vitaliano, P.P.; Zhang, J.; Scanlan, J.M. Is caregiving hazardous to one's physical health? A meta-analysis. Psychol. Bull. 2003, 129, 946-972. [CrossRef]

80. Reinhard, C.S.; Given, B.; Petlick, N.H.; Bemis, A. Supporting family caregivers in providing care. In Patient Safety and Quality. An Evidence-Based Handbook for Nurses; Hughes, R.G., Ed.; Agency for Healthcare Research and Quality: Rockville, MD, USA, 2008; pp. 341-404.

81. Ojel-Jaramillo, J.M.; Cañas, J.J. Enhancing the usability of telecare devices. Hum. Technol. 2006, 1, 103-118. [CrossRef]

82. Colombo, F.; Llena-Nozal, A.; Mercier, J.; Tjadens, F. Help Wanted? Providing and Paying for Long-Term Care; OECD Publishing: Paris, France, 2011.

83. Levin, C.A.; Kane, R.A. Resident and family perspectives on assisted living. J. Aging Soc. Policy 2006, 18, 173-192. [CrossRef] [PubMed]

84. Yamasaki, J.; Sharf, B. Opting out while fitting in: How residents make sense of assisted living and cope with community life. J. Aging Stud. 2011, 25, 13-21. [CrossRef]

(C) 2020 by the authors. Licensee MDPI, Basel, Switzerland. This article is an open access article distributed under the terms and conditions of the Creative Commons Attribution (CC BY) license (http://creativecommons.org/licenses/by/4.0/). 